\title{
Disfluency Characteristics of School-Age Children with High-Functioning Autism Spectrum Disorders
}

\author{
Heeyoung Park, Hyeyeon Park, Dongran Won, Haewon Kim, Seungha Song, Hyun Sub Sim \\ Department of Communication Disorders, Graduate School, Ewha Womans University, Seoul, Korea
}

Correspondence: Hyun Sub Sim, PhD Department of Communication Disorders, Ewha Womans University, 52 Ewhayeodae-gil, Seodamun-gu, Seoul 03760, Korea

Tel: $+82-2-3277-3538$

Fax: +82-2-3277-2122

E-mail: simhs@ewha.ac.kr

Received: April 10, 2018

Revised: May 22, 2018

Accepted: June 8, 2018

This work was supported by BK21 PLUS Project by Korea Government (2017).

\begin{abstract}
Objectives: The purpose of this study was to investigate characteristics of speech disfluency in school-age children with high-functioning autism spectrum disorders (HF-ASD), children who stutter (CWS), and control children on reading, story retelling, and picture description tasks. Methods: Seven HF-ASD, 6 CWS, and 8 control children participated in this study. All participants ranged in age from 6 to 8 years and were matched for age and vocabulary ability. Speech samples were collected from three speaking tasks, and disfluency characteristics were identified and classified as stuttering-like disfluencies (SLD) or other disfluencies (OD). Results: Three groups did not differ in OD frequencies across the three speaking tasks. There was no significant difference between the HF-ASD and CWS groups in total disfluencies (TD) on the picture description task with SLD on the story retelling and picture description tasks. In the HF-ASD group, TD frequency in story retelling and OD frequency in story retelling and picture description were significantly higher compared to their reading performance; SLD frequency did not change significantly across tasks. In SLD subtypes, there was no significant difference in single-syllable repetition, part-word repetition and prolongation frequencies between the HF-ASD and CWS groups, but the CWS group produced more blocks than the HF-ASD group. Conclusion: These results demonstrate that, similar to children who stutter, school-age children with HF-ASD are disfluent in their verbal production except for reading. This finding suggests that the disfluent speech characteristics of HF-ASD children should be considered in evaluation and intervention.
\end{abstract}

Keywords: High-functioning autism spectrum disorder, Stuttering, Other disfluencies, Stuttering-like disfluencies
최근 언어 및 인지능력이 잘 보존된 고기능 자폐스펙트럼장애 (high-functioning autism spectrum disorder, HF-ASD)에 관한 연 구가 활발해지고 있다. DSM-5 (Diagnostic and Statistical Manual of Mental Disorders-5th edition; American Psychiatric Association, 2013)에 의하면 자폐스펙트럼장애(autism spectrum disorder)는 사회적 의사소통 및 상호작용 결함과 제한적이고 반복적인 행동, 관심, 활동이라는 두 가지 핵심영역에 있어 증상에 여러 중증 도 수준(severity level)을 보이는 신경발달장애'로 정의된다. 이중 고기능 자폐스펙트럼장애 아동은 다른 사람의 관점을 이해하는 데 어려움이 있고, 대화에 참여하는 빈도가 낮으며, 적절한 반응을 제공하지 못하는 등 자폐스펙트럼장애의 대표적인 특징들을 보이
나(Paul, Orlovski, Marcinko, \& Volkmar, 2009), 자폐 증상과 언어 적 손상이 상대적으로 가볍고 인지 및 언어능력에서 평균 또는 그 이상의 수준을 보이는 아동들이다(Kjelgaard \& Tager-Flusberg, 2001; O'Connor \& Hermelin, 1994).

고기능 자폐스펙트럼장애에 관한 선행연구들은 일반아동들과 명확한 차이를 보이는 화용론적 결함(pragmatic language deficits) 이외에, 비교적 언어능력의 손상이 두드러지지 않음에도 불구하고 의미, 구문/형태, 음운처리 등의 다양한 언어영역에서 일반아동들 과 차이를 보인다고 보고하였다(Charman, Drew, Baird, \& Baird, 2003; Choi et al., 2015; Kover, McDuffie, Hagerman, \& Abbeduto, 2013; Kover et al., 2014; Rutter, Mawhood, \& Howlin, 1992). 고기 
능 자폐스펙트럼장애의 진단 기준으로 소아기(3세 이전)에 언어발 달과 상징놀이의 지연(American Psychiatric Association, 1994)을 비롯하여 Kover 등(2013)은 4-11세의 고기능 자폐스펙트럼장애 아 동들도 수용 및 표현어휘 모두 정상아동에 비해 유의하게 지연되었 으며 정상아동과는 달리 수용어휘에서 약함을 보인다고 보고하였 다. 또한, Tager-Flusberg (2004)는 고기능 자폐스펙트럼장애 아동 이 언어능력에서의 지체가 크게 부각되지는 않으나 저장된 의미를 효율적으로 처리하는 데 어려움을 보이고, 낮은 구문론적 지식 수 준에서 언어를 구사하여 의사소통 기능에 결함이 있다고 하였다. 고기능 자폐스펙트럼장애 아동의 이야기 말하기를 분석하면 일반 아동보다 이야기 구성능력이 유의하게 낮고(Cho \& Lee, 2017), 담 화적 결속 장치의 사용빈도가 적어 인과관계를 나타내는 데 어려 움을 겪는 것으로 나타났다(Baixauli, Colomer, Roselló, \& Miranda, 2016; Cho \& Lee, 2017).

언어능력의 어려움 이외에 말 산출능력과 관련된 고기능 자폐스 펙트럼장애 연구는 매우 제한적이며 지금까지 대부분의 연구들이 자폐 증상이 뚜렷한 자폐스펙트럼장애군을 대상으로 하였다. 자폐 스펙트럼 관련 선행연구들을 살펴보면 자폐스펙트럼장애 성인과 아동들이 운율과 공명, 강세, 조음, 유창성의 측면에서 어려움을 보 인다고 보고하였다(Paul et al., 2005; Shriberg et al., 2001). 자폐스 펙트럼장애 아동들의 음성은 대체로 음도가 높고, 음도의 범위가 좁아서 단조롭게 들리며(Goldfarb, Goldfarb, Braunstein, \& Scholl, 1972 ; Pronovost, Wakstein, \& Wakstein, 1966), 음질 측면에서도 목쉰 소리나 거친 소리, 과대 비음화의 경향이 나타났다(Pronovost et al., 1966). 또한, 자폐스펙트럼장애 아동들의 운율적 특성의 결함 으로 결핍된 억양과 과도한 강세, 부적절한 구반복과 수정, 부적절 한 속도 등의 비전형적인 운율구를 사용하였고(Bagshaw, 1978; Fletcher, 1976; Fosnot \& Jun, 1999; Goldfarb et al., 1972; Hargrove, 1997; Shriberg et al., 2001), 조음적인 측면에서 자폐스펙트럼장애 아동은 일반아동들에 비해 조음의 속도 및 말속도가 유의하게 느 리며 대화 중 잦은 쉼과 긴 쉼이 나타났다(Park, 2011). Hietala와 Spillers (2005)는 자폐스펙트럼장애로 진단받은 10 대 청소년들의 발화에서 'football-ball'과 같은 끝 음절 반복(final syllable repetition)과 'cat-at'과 같은 '각운 반복(rhyme repetitions)'이 나타난다 고보고하였다.

이와 같이 자폐스펙트럼장애의 특성이 다양한 영역에서 보고되 고 있으며 이들 집단의 이질적인 특징들이 더욱 부각되고 있다. 이 렇게 보고되는 영역 가운데 하나가 이들의 비유창성에 관한 문제 들이다. 현재까지 국외에서 고기능 자폐스펙트럼장애 집단에 관한 비유창성 연구는 소수이며, 국내에서는 더욱 부족한 실정이다. 최
근 들어, 국내외에서 말더듬이 동반되어 나타날 수 있는 여러 장애 군에 대하여 기존 비유창성 분석틀에 맞춰 그들의 비유창성을 분 석하는 시도들이 진행되고 있으나, 대부분 지적장애(mental retardation)와 다운증후군(Down's syndrome), 주의력결핍-과잉행동 장애(attention deficit-hyperactivity disorder, $\mathrm{ADHD}$ ), 아스퍼거 증후군(Asperger's syndrome) 등을 연구대상으로 하였다. 관련 선 행연구들은 지적장애인 중 $2 \%-20 \%$ 가 말더듬을 동반하며(Karlin \& Strazzula, 1952; Schlanger, 1953), 다운증후군 중 $10 \%-45 \%$ 가 말 더듬을 동반한다고 보고하였다(Keane, 1970; Schlanger \& Gottsleben, 1957). ADHD 관련 연구에서는 $\mathrm{ADHD}$ 아동들이 일반아동 에 비해 반복과 간투사가 많이 나타나고(Lim \& Hwang, 2009), 일 반아동보다 정상적 비유창성(other disfluencies, OD)과 비정상적 비유창성(stuttering-like disfluencies, SLD) 빈도가 더 높다라고 보 고하였다(Lee, Sim, Lee, \& Choi, 2017). 특히, 자폐스펙트럼장애 중 고기능 자폐스펙트럼장애와 달리 소아기에 언어발달지연을 보이 지 않는 아스퍼거증후군(American Psychiatric Association, 1994; Klin, Volkmar, \& Sparrow, 2000)의 비유창성 특성에 관한 선행연 구들을 살펴보면, $10-50$ 대의 아스퍼거증후군 중 $67 \%$ 가 음소 및 음 절, 단어 반복과 단단어 수정을 포함한 '부적절한 또는 비유창한 구절'을 나타내며, 이는 발달된 언어능력을 가진 자폐스펙트럼장애 집단에서도 일반적인 운율의 문제를 보이며 부적절한 강세의 사용 과 비정상적인 억양패턴과 과대비성, 유창성의 감소가 아동뿐 아니 라 성인에게도 나타난다고 보고하였다(Shriberg et al., 2001).

아스퍼거증후군 관련 연구를 확장하면, 학령기 아스퍼거증후군 학생들에게서 첫자음 생략 또는 음절 반복 및 낱말 끝소리 반복이 나타났으며(Sisskin, 2006), 성인 아스퍼거증후군에게서 SLD에 포 함되는 낱말 부분 반복과 막힘, $\mathrm{OD}$ 에 포함되는 구반복과 삽입이 나타났다(Scaler Scott, Grossman, Abendroth, Tetnowski, \& Damico, 2006). 또한, 학령전기 아스퍼거 증후군 아동들에게서 음절 사 이 삽입(between syllable insertions)과 단어 내 깨짐(within word breaks), 끝 음소와 음절 반복(final sound and syllable repetitions), 끝 음소 연장(final sound prolongations)과 같은 SLD가 나타났다 고 보고하였다(Plexico, Cleary, McAlpine, \& Plumb, 2010). 학령기 아스퍼거 증후군 집단과 말더듬 집단, 일반 집단의 세 집단 간 비유 창성 빈도와 유형, 낱말 끝소리 반복의 비율을 측정한 연구(Scaler Scott, Tetnowski, Flaitz, \& Yaruss, 2014)에서는 아스퍼거 증후군 집단이 일반아동뿐 아니라 말더듬 집단과 SLD 비율에서 유의미한 차이가 나타났고 아스퍼거 증후군 집단 중 $36 \%$ 가 유창성 장애로 진단되었다. 이러한 결과는 아스퍼거증후군 집단의 비유창성이 말 더듬 집단에서 보이는 비유창성 특성과 양적으로 질적으로 다를 
수 있으며, 말더듬 아동보다 아스퍼거 증후군 아동에게 낱말 끝소 리 반복이 더 공통적인 비유창성 유형으로 나타난다고 제안하였다.

이와 같이 여러 장애군을 대상으로 비유창성 관련 연구가 꾸준 히 진행된 것과 달리 고기능 자폐스펙트럼장애를 대상으로 하는 비유창성 연구는 매우 소수이다. 관련 선행연구를 살펴보면 운율 적인 측면에서 고기능 자폐스펙트럼장애 아동들이 일반아동에 비 해 높은 음도와 과장된 음도변화, 더 넓은 음도범위에서의 발화와 같이 비전형적인 운율패턴을 사용하여 의사소통에 부정적인 영향 을 미치며(Choi, Shin, \& Lee, 2016; Nadig \& Shaw, 2012), 대화에서 완전한 단어를 탐색하기 위한 시도로 수정(revision)이 많이 관찰된 다고 보고하였다(Stirling, Barrington, \& Douglas, 2007). 아스퍼거 증후군와 함께 고기능 자폐스펙트럼장애의 비유창성을 분석한 Shriberg 등(2001)의 연구에서 10-50대의 고기능 자폐스펙트럼장 애 중 $40 \%$ 가 부적절한 또는 비유창한 구절을 나타낸다고 하였다. 그러나 이러한 결과들은 고기능 자폐스펙트럼장애 아동과 성인을 정상화자와 비교한 연구들로 이들의 비유창성 특성이 말더듬 화자 와는 얼마나 다른 양상을 보이는지에 관한 의문점이 남는다. 따라 서 본 연구에서는 고기능 자폐스펙트럼장애의 비유창성 특성이 말 더듬 화자 및 정상화자와 어떠한 차이를 보이는지 자세히 살펴보 고자 하였다. 학령기 고기능 자폐스펙트럼장애 아동을 대상으로 읽기 및 이야기 다시말하기, 그림 설명하기의 서로 다른 발화산출 과제에서 말더듬 아동 및 일반아동들과 비교하여 비유창성의 특 성에 차이가 있는지 알아보았다. 이는 고기능 자폐스펙트럼장애 아 동들의 비유창성 경향을 파악하고 중재가 필요할 경우 효율적인 접근을 위한 기초자료로 활용할 수 있을 것이다. 특히, 최근 문헌들 사이에서 자폐스펙트럼장애 아동들의 비유창성이 말더듬을 수반 한 것인지, 단순 $\mathrm{OD}$ 의 형태인지, 또는 과도한 $\mathrm{OD}$ 를 나타내는지 등 의 정확한 특성 파악에 어려움이 있어 적절한 중재 제공의 필요성 에 관한 우려가 증가하고 있다. 예를 들어, 자폐스펙트럼장애 아동 의 비유창성이 말더듬으로 진단될 경우, 말더듬 치료전략으로 중재 되어야 하며, 단순 $\mathrm{OD}$ 일 경우, 중재의 필요성이 감소하며, 과도한 $\mathrm{OD}$ 일 경우, 언어적 중재 및 자발적인 모니터링과 함께 비유창성을 줄이기 위한 중재가 소개되어야 할 것이다(Scaler Scott, 2008). 이러 한 맥락에서 고기능 자폐스펙트럼장애 아동들의 비유창성 특성을 정확히 파악하고 말더듬 아동 및 일반아동들과의 비유창성의 차 이를 밝히는 것은 매우 중요하다 하겠다. 본 연구의 세부적인 연구 질문은 다음과 같다.

첫째, 세 가지 발화상황에서 집단 간(고기능 자폐스펙트럼장애 아동, 말더듬 아동, 일반아동) 비유창성 특성(TD, $\mathrm{OD}, \mathrm{SLD})$ 에 유 의한차이를 보이는가?
둘째, 세 가지 발화상황에서 집단 내(고기능 자폐스펙트럼장애 아동, 말더듬 아동, 일반아동) 비유창성 특성(TD, $\mathrm{OD}, \mathrm{SLD})$ 에 유 의한차이를 보이는가?

셋째, 세 가지 발화상황에서 집단 간(고기능 자폐스펙트럼장애 아동, 말더듬아동, 일반아동) 비유창성의 하위유형 특성(4가지 OD, 5 가지 SLD)에 유의한 차이를 보이는가?

\section{연구방법}

\section{연구대상}

본 연구는 서울, 경기지역에 거주하고 언어발달이 정상범주에 속 하는 만 6-8세의 고기능 자폐스펙트럼장애 아동(HF-ASD) 7명과 언어와 생활연령을 일치시킨 말더듬 아동(CWS) 6명, 일반아동 (control) 8명을 연구대상자로 하였다. 세 집단은 초등학교 1학년에서 3 학년 학생들로 모두 일반학급에서 학업을 진행 중이며, HF-ASD 집단은 남자 6 명과 여자 1 명, CWS 집단은 남자 5 명과 여자 1 명, control 집단은 남자 4 명과 여자 4 명으로 구성하였다.

HF-ASD 집단은 (1) 소아정신과 또는 신경정신과에서 자폐스펙 트럼장애(autism spectrum disorder)로 진단받은 아동으로 아스퍼 거증후군을 제외하고, (2) 부모 보고에 의해 시각 및 청각 등의 감각 장애를 동반하지 않으며, (3) 한국 카우프만 아동용 지능검사(Korean Kaufman Assessment Battery for Children, K-ABC; Moon \& Byun, 1997)의 비언어성 하위검사에서 동작성 지능점수가 70점 이 상에 속하고, (4) 수용·표현어휘력검사(Receptive and Expressive Vocabulary Test, REVT; Kim, Hong, Kim, Chang, \& Lee, 2009)에 서 수용어휘력 점수가 해당 연령의 평균에서 $-1 \mathrm{SD}$ 이상의 정상어 휘능력을 가진 아동들로 선별하였다. CWS 집단은 (1) 과거에 유창 성장애로 진단받고 현재 주 1 회 또는 2 회 말더듬 언어중재를 받고 있으며, (2) 현재 아동의 비유창성 수준을 평가하기 위하여 파라다 이스-유창성검사-II (Paradise-Fluency Assessment-II, P-FA-II; Sim, Shin, \& Lee, 2010)를 실시한 결과, 말더듬 정도가 약함-중간 사이의 비유창성을 보이는 아동들로, (3) 부모 및 교사 보고에 의해 발달장애와 시각 및 청각 등의 감각장애가 없고, (4) 비유창성 이외 에 언어 및 지능에 문제가 없으며, (5) REVT의 수용어휘력 점수가 해당 연령의 평균에서 -1 SD 이상의 정상어휘능력을 가진 아동들 을 대상으로 하였다. 또한, control 집단은 (1) 부모 및 교사의 보고 에 의해 발달 및 감각적인 장애가 없고, (2) 언어 및 지능에 문제가 없으며, (3) 특수교육 또는 언어치료 경험이 없고, (4) 학교에서 특정 영역의 학업에 문제가 없는 아동들로, (5) REVT의 수용어휘력 점 수가 해당 연령에서 -1 SD 이상의 정상어휘능력을 가지고, (6) 2급 
언어재활사 자격증을 소지한 언어재활사에 의해 말더듬이 아닌 것 으로 진단된 아동들로 선별하였다.

본 연구에 참여한 HF-ASD 집단의 생활연령 평균은 85.86개월(7 세 2개월, $\mathrm{SD}=7.60)$, 교육년수 평균은 1.43 년(SD=.79), $\mathrm{REVT}$ 의 수용어휘 평균은 86.29 점 $(\mathrm{SD}=7.80)$ 으로 8 세 9 개월의 등가연령에 해당하여 평균 생활연령보다 높은 수용어휘능력을 보였다. CWS 집단의 생활연령 평균은 93.00개월(세 9개월, $\mathrm{SD}=5.59$ ), 교육년수 평균은 1.67 년 $(\mathrm{SD}=.52), \mathrm{REVT}$ 의 수용어휘 평균은 92.50 점 $(\mathrm{SD}=$ 3.02)으로 9 세 7개월의 등가연령에 해당하여 평균 생활연령보다 높 았다. 또한, control 집단의 생활연령 평균은 94.38 개월(7세 10 개월, $\mathrm{SD}=9.97)$, 교육년수 평균은 2.25 년(SD=.71), REVT의 수용어휘 평균은 93.75 점 $(\mathrm{SD}=10.22)$ 으로 9 세 8 개월의 등가연령에 해당하여 평균 생활연령보다 높게 나타났다. 세 집단은 대상자 수가 충분하 지 않고 정규분포 가정을 충족시키지 못하는 대상자 요인을 포함 하므로(HF-ASD와 CWS 집단의 교육년수: $p<.01$, Shapiro-Wilk normality test) 비모수검정방법인 Kruskal-Wallis H test를 실시하 여 집단 간 대상자 특성의 차이를 조사하였다. 세 집단은 생활연령 $\left(\chi^{2}=4.52, p=.102\right)$ 및 교육년수 $\left(\chi^{2}=4.96, p=.080\right)$, 수용어휘력 $\left(\chi^{2}\right.$ $=2,74, p=.262)$ 에서 모두 통계적으로 유의한 차이를 보이지 않았 다. 대상자들의 기본 정보는 Table 1 에 제시하였다.

세 집단의 말더듬 중증도의 차이는 다음과 같다. HF-ASD 집단 은 P-FA-II 총점수의 평균이 22.79점(SD=11.67)으로 백분위수가 21-30\%ile에 해당하며 중증도는 약함(개인별: 약함 5명, 중간 2명) 이었고, CWS 집단은 평균 27.85점(SD = 17.99)으로 백분위수 41$50 \%$ ile, 중증도는 중간(개인별: 약함 4 명, 중간 1명, 심함 1명)이었고, control 집단은 평균 9.65점(SD=3.75)으로 백분위수 1-10\%ile, 중 증도는 약함(개인별: 약함 8명)이었다. 집단 간 중증도의 차이를 비 교하기 위하여 Kruskal-Wallis H test (CWS 집단의 P-FA-II 총점 수: $p<.05$, Shapiro-Wilk normality test)를 실시한 결과, 세 집단의 P-FA-II 총점수에서 통계적으로 유의한 차이를 보였다 $\left(\chi^{2}=11.81\right.$, $p=.003)$. Bonferroni 교정을 통한 Mann-Whitney U-test로 사후검 정을 실시한 결과, $\mathrm{HF}-\mathrm{ASD}$ 와 CWS 집단은 유의하지 않은 차이

Table 1. Participants' characteristics

\begin{tabular}{lccc}
\hline & HF-ASD (N=7) & CWS (N=6) & Control (N=8) \\
\hline Age (mo) & $85.86(7.60)$ & $93.00(5.59)$ & $94.38(9.97)$ \\
Education (yr) & $1.43(.79)$ & $1.67(.52)$ & $2.25(.71)$ \\
REVT-R (total scores) & $86.29(7.80)$ & $92.50(3.02)$ & $93.75(10.22)$ \\
\hline
\end{tabular}

Values are presented as mean (SD).

HF-ASD = high-functioning autism spectrum disorders; CWS = children who stutter; REVT-R=Receptive and Expressive Vocabulary Test-Receptive (Kim, Hong, Kim, Jang, \& Lee, 2009).
$(Z=-.57, p=.63)$ 를, $\mathrm{HF}-\mathrm{ASD}$ 와 control 집단은 유의한 차이 $(Z=-2.78$, $p<.01)$ 를, CWS와 control 집단은 유의한 차이 $(Z=-2.97, p<.01)$ 를 보였다.

\section{연구과제 및 절차}

대상자 선별검사

한국 카우프만 아동용 지능검사 $(K-A B C)$

K-ABC (Moon \& Byun, 1997)는 만 2세 6개월에서 12세 5개월까 지의 아동 및 청소년의 지능(intelligence)과 습득도(achievement) 를 측정하기 위해 개발된 개인별 지능검사도구이다. 본 연구에서 $\mathrm{HF}-\mathrm{ASD}$ 아동들의 연구대상자 선정 조건을 검증하기 위한 기초검 사로 K-ABC의 비언어성 검사(손동작, 삼각형, 시각유추, 위치기억, 사진순서)를 실시하여 아동의 동작성 지능을 산출하고, Tsai (1992) 의 기준에 따라 동작성 지능지수 70 점 이상을 선정기준으로 하였다.

\section{수용·표현어휘력검사(REVT)}

REVT (Kim et al., 2009)는 만 2세 6개월부터 만 16세 이상의 아 동 및 성인의 수용어휘능력과 표현어휘능력을 평가하기 위한 표준 화된 언어검사도구이다. 본 연구에서 HF-ASD와 CWS, control 아 동들의 연구대상자 선정 조건을 검증하기 위한 기초검사로 REVT 의 수용어휘력 검사를 실시하였고 해당 연령의 평균에서 -1 SD 이 상을 선별기준으로 하였다. 이는 집단 간 어휘능력이 구어산출의 비유창성에 미치는 영향을 통제하기 위하여 세 집단 모두 동일하게 적용하였다.

\section{실험 과제}

본 연구에서 세 집단의 비유창성 특성을 살펴보기 위하여 P-FAII (Sim et al., 2010)를 실시하였다. P-FA-II는 모든 연령(취학 전, 학 령기, 성인기)을 대상으로 유창성장애 여부와 정도를 평가하기 위 한 표준화된 말더듬 검사도구로 연령수준에 적합한 읽기 및 이야 기 다시말하기, 그림 설명하기 과제를 통한 다양한 발화상황에서 비유창성을 측정할 수 있다. 세 집단은 모두 초등학교 저학년 학생 들을 대상으로 하므로 학령기 아동들의 필수과제인 P-FA-II 읽기 (저학년용), 이야기그림, 말하기그림의 세 가지 검사를 실시하였다. 과제제시순서는 P-FA-II 검사지침에 따라 모든 피험자들에게 읽기, 이야기 그림, 말하기 그림의 동일한 순서로 진행하였다. 세 과제를 통해 수집된 아동의 모든 발화는 디지털 카메라로 녹화하고, 수집 된 발화는 연구자들이 3 일 이내에 개별적으로 전사하여 비유창성 분류 기준에 맞춰 분석하였다. 
읽기

본 연구에서 사용한 읽기과제는 초등학교 저학년 학생에게 사용 하는 '혹부리 영감'과 ‘우리 선생님’이었다. 읽기 자료는 총 600 음절 로 구성되어 있으며 모든 아동에게 동일한 순서('혹부리 영감’ $\rightarrow$ ‘우 리 선생님')로 읽기자료를 제시하고 평소에 읽는 것과 같은 속도로 읽도록 하였다.

이야기 다시말하기

이야기 그림 과제는 읽기과제에서 사용된 '혹부리 영감'의 이야 기로 만들어진 6 개의 이야기그림 카드를 사용하였다. 그림카드의 순서를 섞어서 아동에게 제시하고, 아동이 스스로 순서를 맞춘 후 이야기를 다시 말하도록 하였다. 그림카드의 순서가 맞지 않을 경 우 검사자가 이야기 순서대로 수정해 주었다. 이야기 그림 과제에서 300 음절 이상 충분한 발화가 수집되지 못할 경우 검사자가 질문을 통해 아동에게 추가적인 발화를 유도하였다.

\section{단일그림 설명하기}

말하기 그림 과제는 초등학교 저학년을 대상으로 하는 '운동회' 와 ‘우리동네’를 사용하였다. 모든 아동에게 동일한 순서('운동회' $\rightarrow$ '우리동네')로 그림을 제시하고 각 그림을 보면서 상황과 등장인 물에 대해 자세히 설명하도록 하였다. 아동이 그림을 설명할 때 빠 뜨린 내용이 있다면 질문으로 유도하고 두 그림에서 300 음절 이상 충분한 발화가 수집되지 못할 경우에도 검사자가 질문을 통해 아 동에게 추가적인 발화를 유도하였다.

\section{연구 절차}

검사는 $\mathrm{HF}-\mathrm{ASD}$ 와 CWS 집단은 2 회, control 집단은 1 회에 걸쳐 소음이 없는 조용한 방이나 치료실에서 개별적으로 실시하였고 검 사절차는 집단에 따라 다르게 진행하였다. HF-ASD 아동은 첫 번 째 방문에 고기능 자폐스펙트럼장애의 대상 선정을 위한 기초적 선 별검사로 K-ABC와 REVT를 먼저 실시하였고, 두 번째 방문에 비 유창성 특성을 평가하기 위해 P-FA-II를 실시하였다. 이에 반해, CWS 아동은 과거에 말더듬 진단을 받은 아동들로 첫 번째 방문에 연구대상 확인 및 현재의 말더듬 정도를 평가하기 위하여 P-FA-II 를 먼저 실시하였고, 두 번째 방문에 REVT를 실시하였다. 마지막 으로, control 아동은 1 회 방문에 REVT와 P-FA-II를 함께 실시하 였다. 모든 검사는 REVT와 P-FA-II 검사에 익숙한 1급 또는 2급 언 어재활사 자격증을 소지한 연구자들이 검사를 다시 충분히 숙지 한 후 실시하였다.

\section{자료 분석}

아동으로부터 수집한 발화자료 중 총 900 음절을 사용하여 비유 창성 특성을 분석하였다. 불분명한 발화는 전사에서 제외하였고, 전사된 발화 중 첫 50 음절을 제외하고 읽기과제에서 500 음절, 이야 기 그림 과제와 말하기 그림 과제에서 각각 200음절을 세어 분석 발화에 포함하였다. 과제별로 총 음절수가 상이하므로 원점수의 비유창성 빈도가 아닌 ' 100 음절당 비유창성 빈도'를 분석단위로 사용하였다.

본 연구에서 아동들의 비유창성을 평가하기 위하여 각 과제에서 비유창성 빈도를 하위유형별로 분류하여 산출하였다. Ambrose와 Yairi (1999)의 비유창성 분류기준에 따라 TD을 OD와 SLD로 나 누고, $\mathrm{OD}$ 에 간투사(interjection), 수정(revision), 다음절낱말반복 (multisyllable repetition), 구반복(phrase repetition)의 네 가지 하 위유형을 포함하고, SLD에 일음절낱말반복(single-syllable repetition), 낱말부분반복(part-word repetition), 연장(prolongation), 막 힘(block), 깨진 낱말(broken word)의 다섯 가지 하위유형을 포함 하였다. $\mathrm{OD}$ 는 발달상 일반아동들에게도 흔히 관찰될 수 있으나 지속시간 및 빈도, 질적 양상에 유의미한 차이를 보일 경우 중재의 대상이 될 수 있으며, SLD는 말더듬 아동들에게서 나타나는 주요 형태들로 양적, 질적인 측면에서 말더듬 초기부터 $\mathrm{OD}$ 와는 변별되 는 유형으로 시간 경과에 따라 말더듬의 변화를 가장 민감하게 살 펴볼수 있는 임상적 지표로 사용되고 있다(Yairi, Ambrose, \& Niermann, 1993). 본 연구에서 사용한 비유창성 하위유형의 분류와 정 의는 Table 2에 제시하였다.

\section{신뢰도 및 통계처리}

평가자 간 신뢰도

자료 분석에 앞서 전사와 비유창성 유형 및 빈도 분석에 관한 신 뢰도를 높이기 위하여 평가자 훈련을 실시하였다. 본 연구의 제 3,4 저자인 2 인은 모두 언어재활사 2 급 자격증을 소지하고 2년 이상 언 어치료기관에 재직한 경험이 있는 언어병리학과 석사과정의 연구 자들이다. 본 연구의 자료 예비분석 시 녹화한 평가 자료를 시청하 며 언어재활사 1 급 자격증을 소지하고 유창성장애를 전공하는 박 사과정의 제 2 저자의 지도하에 전사 및 분석 방법을 훈련하였다. 2 인의 평가자 간 일치도가 서로 다른 과제에서 연속 2 회 $95 \%$ 이상 나타날 때까지 평가자 훈련을 지속하였다.

실험과제의 평가자 간 신뢰도를 구하기 위하여 전체 21 명의 피험 자 중 무작위로 선택한 4 명(19\%에 해당)의 자료를 바탕으로 연구자 2 인의 신뢰도를 구하였다. 연구자가 개별적으로 세 과제(총 900 음 절)를 독립적으로 전사하고 비유창성 유형을 분석하여, 일치한 유 
Table 2. Classification of speech disfluency subtypes (Ambrose \& Yairi, 1999)

\begin{tabular}{|c|c|}
\hline Speech disfluencies & Definition \\
\hline \multicolumn{2}{|l|}{ OD } \\
\hline Interjection & The insertion of words or syllables between target words that do not relate to the meaning of the word ("um", "uh", "like") \\
\hline Revision & The change in pronunciation, vocabulary, grammatical structure, and content of an already delivered word ("mom ate/ mom fixed dinner") \\
\hline Multisyllable repetition & Repeating multiple syllable words ("because because") \\
\hline Phrase repetition & Repeating phrases ("I want I want go home") \\
\hline \multicolumn{2}{|l|}{ SLD } \\
\hline Single-syllable repetition & Repeating a one syllable word ("but-but", "my-my-my") \\
\hline Part-word repetition & Repeating phonemes or syllables in a word ("b-b-b-ball”, "thi-thi-this”) \\
\hline Prolongation & Sound and airflow continue but the movement of the articulation organs stops. ("mmmammy", "cooookie") \\
\hline Block & $\begin{array}{l}\text { The suspension of air or voice flow and articulation in speech, Inappropriate muscle movement of the larynx, stops or moves. } \\
\text { ("I like to - go home") }\end{array}$ \\
\hline Broken word & Pauses within a word ("0 - pen") \\
\hline
\end{tabular}

$\mathrm{OD}=$ other disfluencies; $S L D=$ stuttering-like disfluencies.

형의 빈도수를 일치한 유형의 빈도수와 불일치한 유형의 빈도수를 더한 수로 나눈 값에 100 을 곱하여 비유창성 유형에 따른 빈도의 평가자 간 신뢰도를 구하였다. OD에서 평가자 간 신뢰도는 $95.31 \%$, SLD에서 평가자 간 신뢰도는 $93.55 \%$ 로 나타났다.

\section{통계 처리}

측정된 모든 자료의 정규성 검정을 위하여 Shapiro-Wilk normality test를 실시하였다. 읽기, 이야기 다시말하기, 그림 설명하기 의 세 가지 발화과제에서 고기능 자폐스펙트럼장애 아동과 말더듬 아동, 일반아동의 세 집단 간 비유창성 빈도에 유의한 차이가 있는지 살펴보기 위하여 비모수검정의 Kruskal-Wallis H test를 실시하고, 집단별 비교를 위한 사후검정으로 Bonferroni 교정을 통한 MannWhitney $U$-test를 실시하였다. 각 집단 내에서 세 가지 발화과제 간 비유창성 빈도에 유의한 차이가 있는지 살펴보기 위하여 비모수검 정의 Friedman test를 실시하고, 과제별 비교를 위한 사후검정으로 Bonferroni 교정을 통한 Wilcoxon signed-ranks test를 실시하였다. 사후검정의 Bonferroni 교정에서 각 짝의 검정 유의수준은 $.05 / 3=$ .0167로 하였다. 본 연구의 모든 자료분석은 IBM SPSS statistics ver$\operatorname{sion} 21.0$ 프로그램을 사용하여 분석하였다.

\section{연구결과}

\section{집단 간 과제의 비유창성 빈도 차이}

고기능 자폐스펙트럼장애 아동이 말더듬 아동 및 일반아동과 읽기, 이야기 다시말하기, 그림 설명하기의 세 가지 발화과제에서 $\mathrm{TD}(\mathrm{OD}+\mathrm{SLD})$ 와 $\mathrm{OD}, \mathrm{SLD}$ 빈도에 유의한 차이를 보이는지 살펴 보기 위하여 비모수검정방법인 Kruskal-Wallis H test를 실시하고,
집단 간 비교를 위한 사후검정으로 Bonferroni 교정을 통한 MannWhitney U-test를 실시하였다. 이는 세 집단 모두 대상자 수가 충분 하지 못하고 Shapiro-Wilk 정규성 검정에서 집단 내 일부 변인들이 정규성을 만족하지 못하기 때문이다. 먼저, 읽기, 이야기 다시말하 기, 그림 설명하기의 3 가지 발화과제에서 세 집단 간 총비유창성 (TD) 빈도의 차이를 살펴보기 위해 Kruskal-Wallis H test를 실시 한 결과, 그림 설명하기 과제에서 세 집단 간 TD 빈도에 유의한 차 이가 나타났고 $\left(\chi^{2}=12.82, p<.001\right)$, 읽기와 이야기 다시말하기 과제 에서는 유의한 차이가 나타나지 않았다(읽기: $\chi^{2}=1.90, p=.400$; 이 야기 다시말하기: $\chi^{2}=4.36, p=.112$ ). 그림 설명하기에서 $\mathrm{TD}$ 빈도의 집단 간 비교를 위해 Bonferroni 교정(유의기준 $p=.0167)$ 을 통한 Mann-Whitney U-test를 실시한 결과, HF-ASD 집단은 CWS 집단 과 통계적으로 유의한 차이가 보이지 않았고 $(Z=-1.50, p=.147)$, control 집단과 유의한 차이를 보였다 $(Z=-2.63, p<.01)$. 또한 CWS 집단과 control 집단은 통계적으로 유의한 차이를 보였다 $(Z=-3.13$, $p<.001)$. 이는 그림 설명하기 과제에서 HF-ASD 아동들의 총비유 창성 빈도가 말더듬 아동들과 차이가 없으며 두 집단 모두 일반아 동들보다 유의하게 높게 나타남을 보여준다.

세 가지 발화과제에서 세 집단 간 $\mathrm{OD}$ 빈도의 차이를 알아보기 위하여 Kruskal-Wallis H test를 실시한 결과, 세 가지 과제 모두에 서 세 집단 간 $\mathrm{OD}$ 빈도에 유의한 차이가 나타나지 않았다(읽기: $\chi^{2}=$ $2.09, p=.365$; 이야기 다시말하기: $\chi^{2}=.62, p=.747$; 그림 설명하기: $\left.\chi^{2}=5.58, p=.056\right)$. 이는 HF-ASD 아동들의 OD 빈도가 세 가지 발 화과제 모두에서 말더듬 아동 및 일반아동들과 유의한 차이가 없 음을 보여준다.

세 가지 발화과제에서 세 집단 간 SLD 빈도의 차이를 살펴보기 위하여 Kruskal-Wallis H test를 실시한 결과, 세 집단 간 SLD 빈도 
Table 3. Descriptive statistics and Kruskal-Wallis $\mathrm{H}$ test results for comparison of three groups by frequency of OD, SLD, and TD per 100 syllables on reading, story retelling, and picture description tasks (500, 200, and 200 syllables)

\begin{tabular}{|c|c|c|c|c|c|c|}
\hline & & HF-ASD (N=7) & CWS (N=6) & Control (N=8) & $x^{2}$ & $p$-value \\
\hline \multirow[t]{3}{*}{ Reading } & $\mathrm{OD}$ & $.80(2.00)$ & $.50(.40)$ & $.70(1.20)$ & 2.09 & .365 \\
\hline & SLD & $1.40(3.00)$ & $1.80(2.20)$ & $.90(3.00)$ & 2.34 & .322 \\
\hline & TD & $2.80(4.00)$ & $2.30(2.60)$ & $1.60(4.20)$ & 1.90 & .400 \\
\hline \multirow[t]{3}{*}{ Story retelling } & OD & $3.00(7.88)$ & $1.60(8.16)$ & $1.75(7.50)$ & .62 & .747 \\
\hline & SLD & $2.00(2.50)$ & $3.75(14.32)$ & $.50(1.00)$ & 14.86 & $.000^{* * *}$ \\
\hline & TD & $5.50(8.06)$ & $6.06(21.48)$ & $2.50(8.00)$ & 4.36 & .112 \\
\hline \multirow[t]{3}{*}{ Picture description } & $\mathrm{OD}$ & $3.00(11.00)$ & $4.25(6.50)$ & $1.50(2.50)$ & 5.58 & .056 \\
\hline & SLD & $1.00(4.50)$ & $4.00(9.50)$ & $.25(1.00)$ & 11.40 & $.001^{* * *}$ \\
\hline & TD & $4.00(15.50)$ & $8.75(12.50)$ & $2.50(2.50)$ & 12.82 & $.000^{* * * *}$ \\
\hline
\end{tabular}

Values are presented as median (range $=$ maximum-minimum).

$\mathrm{OD}=$ other disfluencies; $\mathrm{SLD}=$ stuttering-like disfluencies; $\mathrm{TD}=$ total disfluencies; $\mathrm{HF}-\mathrm{ASD}=$ high-functioning autism spectrum disorders; CWS=children who stutter. ${ }^{* * *} p<.001$.

Table 4. Follow-up Mann-Whitney U-test results for group comparisons (two speaking tasks)

\begin{tabular}{|c|c|c|c|c|c|}
\hline & & & $\begin{array}{c}\text { Mann- } \\
\text { Whitney U }\end{array}$ & Z & $p$-value \\
\hline \multirow{3}{*}{$\begin{array}{l}\text { Story } \\
\text { retelling }\end{array}$} & \multirow[t]{3}{*}{ SLD } & HF-ASD vs. CWS & 5.50 & -2.22 & .026 \\
\hline & & HF-ASD vs. Control & 3.50 & -2.88 & $.003^{\mathrm{a}}$ \\
\hline & & CWS vs. Control & .00 & -3.13 & $.001^{\mathrm{a}}$ \\
\hline \multirow{6}{*}{$\begin{array}{l}\text { Picture } \\
\text { description }\end{array}$} & \multirow[t]{3}{*}{ SLD } & HF-ASD vs. CWS & 6.50 & -2.10 & .037 \\
\hline & & HF-ASD vs. Control & 11.50 & -2.00 & .048 \\
\hline & & CWS vs. Control & 1.50 & -2.97 & $.003^{\mathrm{a}}$ \\
\hline & \multirow[t]{3}{*}{ TD } & HF-ASD vs. CWS & 10.50 & -1.50 & .147 \\
\hline & & HF-ASD vs. Control & 5.50 & -2.63 & $.005^{\mathrm{a}}$ \\
\hline & & CWS vs. Control & .00 & -3.13 & $.000^{\mathrm{a}}$ \\
\hline
\end{tabular}

$\mathrm{SLD}=$ stuttering-like disfluencies; $T \mathrm{D}=$ total disfluencies; HF-ASD = high-functioning autism spectrum disorders; CWS= children who stutter.

${ }^{a} B$ Bonferroni corrected significance level $=.0167$.

의 차이가 읽기 $\left(\chi^{2}=2.34, p=.322\right)$ 를 제외한 이야기 다시말하기와 그림 설명하기 과제에서 유의하게 나타났다(이야기 다시말하기: $\chi^{2}$ $=14.86, p<.001$; 그림 설명하기: $\left.\chi^{2}=11.40, p<.001\right)$. 이야기 다시말 하기와 그림 설명하기의 두 가지 과제에서 각각 SLD 빈도의 집단 간 비교를 위해 사후검정을 실시한 결과, 이야기 다시말하기 과제에서 $\mathrm{HF}-\mathrm{ASD}$ 집단은 CWS 집단과 유의한 차이가 없는 반면( $Z=-2.22$, $p=.026)$, control 집단과 유의한 차이를 보였다 $(Z=-2.88, p<.01)$. 그 림 설명하기 과제에서는 HF-ASD 집단이 CWS 집단과 유의한 차이 가 없었고 $(Z=-2.10, p=.037), \operatorname{control}$ 집단과도 유의한 차이를 보이 지 않았다 $(Z=-2.00, p=.048)$. 또한, CWS 집단과 control 집단은 이 야기 다시말하기와 그림 설명하기의 두 가지 과제 모두에서 통계적 으로 유의한 차이를 보였다(이야기 다시말하기: $Z=-3.13, p<.001$; 그림 설명하기: $Z=-2.97, p<.01)$. 이는 이야기 다시말하기 과제에서 $\mathrm{HF}-\mathrm{ASD}$ 아동들의 SLD 빈도가 말더듬 아동들과 차이가 없으며 두

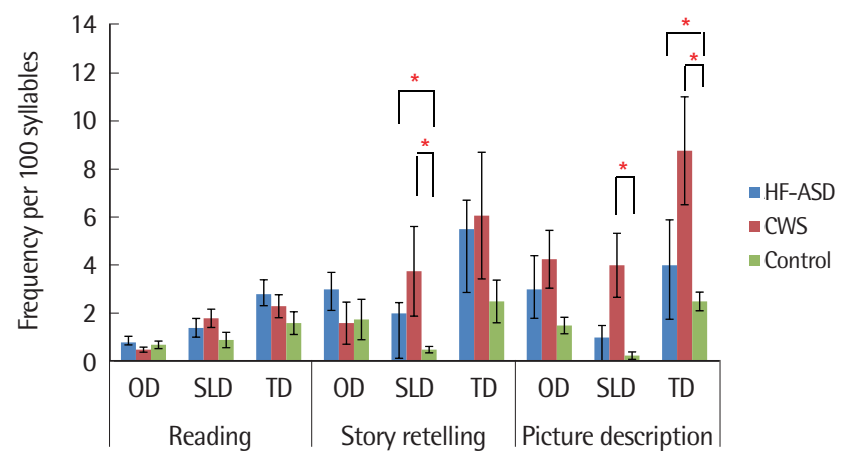

Figure 1. Comparisons for three groups by frequency of OD, SLD, and TD on reading, story retelling, and picture description tasks ( ${ }^{*}$ Significant level $\left.=.0167\right)$. $\mathrm{OD}=$ other disfluencies; $S L D=$ stuttering-like disfluencies; $T D=$ total disfluencies; HF-ASD=high-functioning autism spectrum disorders; CWS=children who stutter.

집단 모두 일반아동들보다 유의하게 높게 나타남을 보여준다. 이에 반해, 그림 설명하기 과제에서 HF-ASD 아동들의 SLD 빈도가 말더 듬 아동들과 차이가 없는 반면, 일반아동들과 비교했을 때 상대적 으로 높은 SLD 빈도(HF-ASD의 SLD 중위수 $=1.00$, control의 SLD 중위수 $=.25 ; \mathrm{HF}-\mathrm{ASD}$ 가 4 배 높음)를 보임에도 불구하고 통계적으 로는 유의하게 다르지 않음을 보여준다. 즉, 그림 설명하기 과제에서 HF-ASD 아동들은 말더듬 아동들과 유사한 빈도로 SLD가 나타나 나, 그 빈도가 일반아동들과 통계적으로 유의한 차이를 보이지 않 음을 의미한다. 과제종류에 따른 집단 간 비유창성 빈도와 사후검 정 결과를 Tables 3과 4, Figure 1에 제시하였다.

\section{집단 내 과제의 비유창성 빈도 차이}

각 집단 내에서 세 가지 발화과제의 $\mathrm{TD}$ 와 $\mathrm{OD}, \mathrm{SLD}$ 빈도에 유의 한 차이가 있는지 알아보기 위하여 비모수검정방법인 Friedman 
test를 실시하고, 과제 간 비교를 위한 사후검정으로 Bonferroni 교 정을 통한 Wilcoxon signed-ranks test를 실시하였다. 먼저, 각 집단 내에서 세 가지 발화과제별 TD 빈도의 차이를 살펴보기 위하여 Friedman test를 실시한 결과, HF-ASD 집단과 CWS 집단은 과제 간 TD 빈도에 유의한 차이가 나타났고(HF-ASD: $\chi^{2}=7.71, p<.05$; CWS: $\left.\chi^{2}=9.48, p<.01\right)$, control 집단은 유의한 차이를 나타내지 않 았다 $\left(\chi^{2}=3.16, p=.232\right) . \mathrm{HF}-\mathrm{ASD}$ 와 CWS의 각 집단 내 과제별 $\mathrm{TD}$ 빈도의 차이를 비교하기 위하여 Bonferroni 교정(유의기준 $p=.0167$ ) 을 통한 Wilcoxon signed-ranks test를 실시한 결과, HF-ASD 집단 에서만 읽기와 이야기 다시말하기의 $\mathrm{TD}$ 빈도 간에 유의한 차이가 나타났고 $(Z=-2.37, p<.016), \mathrm{CWS}$ 집단은 과제 간 TD 빈도가 읽기 와 이야기 다시말하기 $(p=.031)$, 읽기와 그림 설명하기 $(p=.031)$ 간 에 차이가 났으나 통계적으로 유의하지는 않았다. 이는 HF-ASD 아동들이 읽기과제보다 이야기 다시말하기 과제에서 총비유창성 빈도가 유의하게 높게 나타남을 보여준다.

각 집단 내 발화과제별 $\mathrm{OD}$ 빈도의 차이를 알아보기 위하여 Friedman test를 실시한 결과, HF-ASD, CWS, control 세 집단 모두 유의 한 차이를 나타냈다(HF-ASD: $\chi^{2}=11.19, p<.01$; CWS: $\chi^{2}=6.87$, $p<.05$; control: $\left.\chi^{2}=7.03, p<.05\right)$. 각 집단 내 과제 간 $\mathrm{OD}$ 빈도를 비 교하기 위해 Bonferroni 사후검정을 실시한 결과, HF-ASD 집단만 읽기와 이야기 다시말하기의 $\mathrm{OD}$ 빈도 $(Z=-2.37, p<.016)$, 읽기와

Table 5. Follow-up Wilcoxon signed-ranks test results for task comparisons

\begin{tabular}{|c|c|c|c|c|}
\hline & & & Wilcoxon Z & $p$-value \\
\hline \multirow[t]{6}{*}{ HF-ASD } & OD & Reading vs. Story retelling & -2.37 & $.016^{\mathrm{a}}$ \\
\hline & & Reading vs. Picture description & -2.37 & $.016^{\mathrm{a}}$ \\
\hline & & Story retelling vs. Picture description & -.73 & .563 \\
\hline & TD & Reading vs. Story retelling & -2.37 & $.016^{\mathrm{a}}$ \\
\hline & & Reading vs. Picture description & -1.69 & .109 \\
\hline & & Story retelling vs. Picture description & -.34 & .813 \\
\hline \multirow[t]{9}{*}{ CWS } & OD & Reading vs. Story retelling & -1.99 & .063 \\
\hline & & Reading vs. Picture description & -2.20 & .031 \\
\hline & & Story retelling vs. Picture description & -.94 & .438 \\
\hline & SLD & Reading vs. Story retelling & -2.21 & .031 \\
\hline & & Reading vs. Picture description & -2.20 & .031 \\
\hline & & Story retelling vs. Picture description & -1.21 & .313 \\
\hline & TD & Reading vs. Story retelling & -2.20 & .031 \\
\hline & & Reading vs. Picture description & -2.21 & .031 \\
\hline & & Story retelling vs. Picture description & -.14 & 1.00 \\
\hline \multirow[t]{3}{*}{ Control } & OD & Reading vs. Story retelling & -2.17 & .031 \\
\hline & & Reading vs. Picture description & -1.82 & .078 \\
\hline & & Story retelling vs. Picture description & -.68 & .563 \\
\hline
\end{tabular}

HF-ASD = high-functioning autism spectrum disorders; CWS=children who stutter; $\mathrm{OD}=$ other disfluencies; $\mathrm{SLD}=$ stuttering-like disfluencies; $\mathrm{TD}=$ total disfluencies. ${ }^{a}$ Bonferroni corrected significance level $=.0167$.
그림 설명하기의 $\mathrm{OD}$ 빈도 $(Z=-2.37, p<.016)$ 간에 유의한 차이를 보였다.CWS 집단에서 읽기와 그림 설명하기의 $\mathrm{OD}$ 빈도 간 $(p=.031)$ 에, control 집단에서 읽기와 이야기 다시말하기의 $\mathrm{OD}$ 빈도 간에 $(p=.031)$ 차이가 났으나 통계적으로 유의하지는 않았다. 이는 HF$\mathrm{ASD}$ 아동들이 읽기과제보다 이야기 다시말하기와 그림 설명하기 과제에서 $\mathrm{OD}$ 빈도가 유의하게 높게 나타나며 이야기 다시말하기 와 그림 설명하기 간에는 차이가 없음을 보여준다.

각 집단 내 과제별 SLD 빈도의 차이를 살펴보기 위해 Friedman test를 실시한 결과, CWS 집단만 과제 간 SLD 빈도에 유의한 차이 가 나타났고 $\left(\chi^{2}=10.17, p<.01\right)$, Bonferroni 사후검정에서 읽기와 이야기 다시말하기의 SLD 빈도( $p=.031)$, 읽기와 그림 설명하기의 $\mathrm{SLD}$ 빈도 간 $(p=.031)$ 에 차이가 있으나 통계적으로 유의하지 않았 다. 각 집단 내 과제 간 비유창성 비교를 위한 사후검정 결과를 $\mathrm{Ta}-$ ble 5와 Figure 2에 제시하였다.

\section{집단 간 $\mathrm{OD}$ 와 $\mathrm{SLD}$ 의 하위유형별 특성 비교}

Table 6은 읽기, 이야기 다시말하기, 그림 설명하기의 세 가지 발 화과제를 통해 수집된 전체 900 음절에서 OD의 4 가지 하위유형별 비유창성 빈도와 SLD의 5가지 하위유형별 비유창성 빈도를 보여 준다. $\mathrm{OD}$ 의 4 가지 하위유형은 간투사와 수정, 다음절낱말반복, 구 반복을 포함하고, SLD의 5가지 하위유형은 일음절낱말반복, 낱말 부분반복, 연장, 막힘, 깨진 낱말을 포함한다. 전체 OD의 빈도는 HF-ASD 아동들에게서 가장 높았고, 전체 SLD의 빈도는 CWS 아 동들에게서 가장 높게 나타났다.

전체 발화과제에서 산출된 OD와 SLD의 9가지 하위유형에서 세 집단 간 비유창성 빈도의 차이를 살펴보기 위해 Kruskal-Wallis $\mathrm{H}$ test를 실시한 결과, $\mathrm{SLD}$ 의 일음절낱말반복 $\left(\chi^{2}=7.85, p<.05\right)$ 과 낱

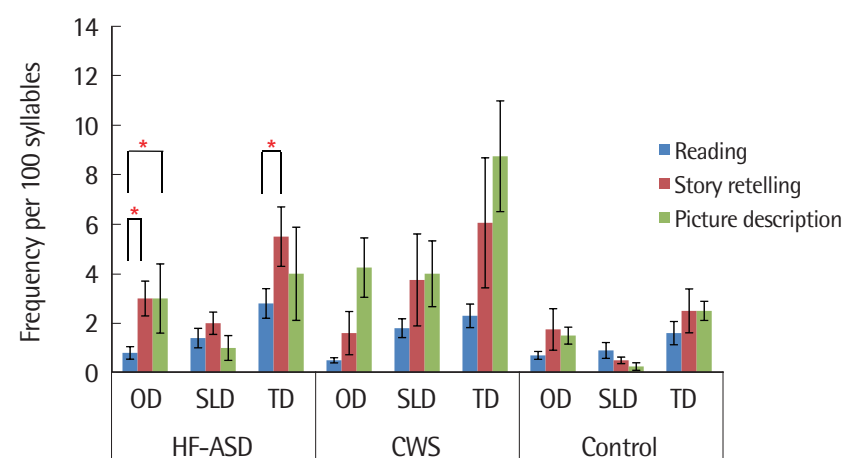

Figure 2. Comparisons for three speaking tasks by frequency of OD, SLD, and TD in each group ( ${ }^{*}$ Significant level $=.0167$ ).

$\mathrm{OD}=$ other disfluencies; $S L D=$ stuttering-like disfluencies; $T D=$ total disfluencies; HF-ASD= high-functioning autism spectrum disorders; $C W S=$ children who stutter. 
Table 6. Descriptive statistics and Kruskal-Wallis H test results for comparison of three groups by frequency of OD and SLD subtypes per 100 syllables (900 syllables in all three tasks)

\begin{tabular}{|c|c|c|c|c|c|}
\hline & HF-ASD (N=7) & CWS $(N=6)$ & Control $(\mathrm{N}=8)$ & $x^{2}$ & $p$-value \\
\hline OD & $2.22(3.67)$ & $1.51(2.99)$ & $1.44(2.00)$ & 1.52 & .49 \\
\hline Interjection & $.33(3.11)$ & $.61(2.57)$ & $.06(1.11)$ & 2.37 & .316 \\
\hline Revision & $1.22(1.15)$ & $.84(.65)$ & $.83(.89)$ & 2.48 & .299 \\
\hline Multisyllable repetition & $.22(.57)$ & $.00(.11)$ & $.11(.44)$ & 5.33 & .065 \\
\hline Phrase repetition & $.00(.56)$ & $.00(.11)$ & $.06(.22)$ & .27 & .89 \\
\hline SLD & $1.37(1.89)$ & $2.82(6.14)$ & $.72(2.11)$ & 9.68 & $.004^{* *}$ \\
\hline Single-syllable repetition & $.11(.33)$ & $.22(.46)$ & $.00(.11)$ & 7.85 & $.015^{*}$ \\
\hline Part-word repetition & $.68(1.44)$ & $1.58(4.13)$ & $.06(.33)$ & 14.81 & $.000^{* * *}$ \\
\hline Prolongation & $.22(.78)$ & $1.67(.47)$ & $.00(.11)$ & 7.48 & $.018^{*}$ \\
\hline Block & $.11(.22)$ & $.58(1.34)$ & $.00(.11)$ & 14.76 & $.000^{* * *}$ \\
\hline Broken word & $.33(.67)$ & $.00(1.11)$ & $.50(2.00)$ & 4.31 & .115 \\
\hline TD (OD+SLD) & $4.56(5.33)$ & $4.38(7.71)$ & $1.83(3.11)$ & 8.50 & $.009^{* *}$ \\
\hline
\end{tabular}

Values are presented as median (range = maximum-minimum).

HF-ASD= high-functioning autism spectrum disorders; $C W S=$ children who stutter; $O D=$ other disfluencies; $S L D=$ stuttering-like disfluencies; $T D=$ total disfluencies.

${ }^{*} p<.05,{ }^{* *} p<.01,{ }^{* * *} p<.001$.

Table 7. Follow-up Mann-Whitney U-test results for group comparisons (SLD subtypes)

\begin{tabular}{llccc}
\hline & & $\begin{array}{c}\text { Mann- } \\
\text { Whitney U }\end{array}$ & Z & p-value \\
\hline Single-syllable & HF-ASD vs. CWS & 17.00 & -.59 & .615 \\
repetition & HF-ASD vs. Control & 6.50 & -2.76 & $.008^{\mathrm{a}}$ \\
& CWS vs. Control & 9.50 & -2.19 & .055 \\
Part-word repeti- & HF-ASD vs. CWS & 9.00 & -1.73 & .098 \\
tion & HF-ASD vs. Control & 1.00 & -3.17 & $.001^{\mathrm{a}}$ \\
& CWS vs. Control & .50 & -3.08 & $.001^{\mathrm{a}}$ \\
Prolongation & HF-ASD vs. CWS & 18.00 & -.44 & .702 \\
& HF-ASD vs. Control & 5.00 & -2.89 & $.004^{\mathrm{a}}$ \\
& CWS vs. Control & 13.50 & -1.70 & .125 \\
Block & HF-ASD vs. CWS & 1.00 & -2.89 & $.003^{\mathrm{a}}$ \\
& HF-ASD vs. Control & 14.50 & -1.87 & .082 \\
& CWS vs. Control & .000 & -3.31 & $.000^{\mathrm{a}}$ \\
\hline
\end{tabular}

SLD=stuttering-like disfluencies; HF-ASD= high-functioning autism spectrum disorders; CWS = children who stutter.

aBonferroni corrected significance level $=.0167$.

말부분반복 $\left(\chi^{2}=14.81, p<.001\right)$, 연장 $\left(\chi^{2}=7.48, p<.05\right)$, 막힘 $\left(\chi^{2}=\right.$ $14.76, p<.001)$ 에서 세 집단 간 비유창성 빈도에 유의한 차이가 나 타났다. 일음절낱말반복과 낱말부분반복, 연장, 막힘에서 비유창성 빈도의 집단 간 비교를 위해 Bonferroni 교정(유의기준 $p=.0167$ )을 통한 Mann-Whitney $U$-test로 사후검정을 실시한 결과, 일음절낱 말반복과, 낱말부분반복, 연장에서 HF-ASD 집단은 CWS 집단과 유의한 차이가 없는 반면(일음절낱말반복: $Z=-.59, p=.615$; 낱말 부분반복: $Z=-1.73, p=.098$; 연장: $Z=-.44, p=.702)$, control 집단 과 유의한 차이를 보였다(일음절낱말반복: $Z=-2.76, p<.01$; 낱말

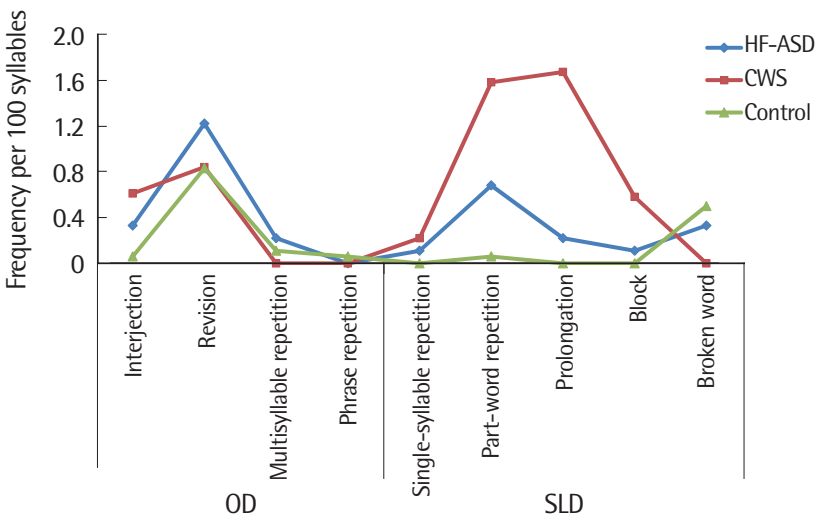

Figure 3. Comparisons for three groups by frequency of OD and SLD subtypes. $\mathrm{OD}=$ other disfluencies; $\mathrm{SLD}=$ stuttering-like disfluencies; HF-ASD = high-functioning autism spectrum disorders; $\mathrm{CWS}=$ children who stutter.

부분반복: $Z=-3.17, p<.001$; 연장: $Z=-2.89, p<.01)$. 또한 CWS집 단과 control 집단은 낱말부분반복에서만 통계적으로 유의한 차이 를 보였다 $(Z=-3.08, p<.01)$. 이는 일음절낱말반복과 낱말부분반 복, 연장에서 $\mathrm{HF}-\mathrm{ASD}$ 아동들의 비유창성 빈도가 말더듬 아동들 과 차이가 없으며 일반아동들보다는 유의하게 높음을 보여준다. 이와 반대로, 막힘에서 HF-ASD 집단은 CWS 집단과 유의한 차이 가 있었고 $(Z=-2.89, p<.01)$, control 집단과 유의한 차이를 보이지 않았다 $(Z=-1.87, p=.082)$. 또한 CWS집단과 control 집단은 막힘 에서 통계적으로 유의한 차이를 보였다 $(Z=-3.31, p<.001)$. 이는 막 힘에서 HF-ASD 아동의 비유창성 빈도가 말더듬 아동들보다 유의 하게 낮으며 일반아동들과 차이가 없음을 보여준다. OD와 SLD 하 
Table 8. Proportions of OD and SLD subtypes in the TD frequency for HF-ASD, CWS, and control groups

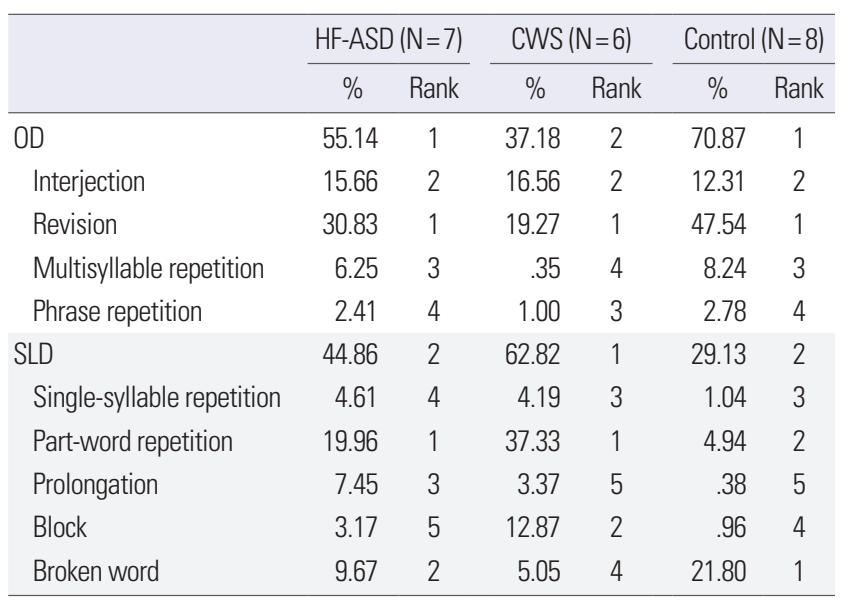

$\mathrm{OD}=$ other disfluencies; $\mathrm{SLD}=$ stuttering-like disfluencies; $\mathrm{TD}$ = total disfluencies; HF-ASD = high-functioning autism spectrum disorders; $C W S=$ children who stutter.

위유형별 집단 간 차이를 살펴보기 위한 사후검정 결과를 Table 7 과 Figure 3 에 제시하였다.

각 집단 내에서 하위유형별 비유창성 비율의 출현순위를 알아보 기 위하여 3 가지 과제에서 나타난 전체 비유창성 빈도에서 각 하위 유형별 비유창성의 빈도를 백분율로 계산하여(예: 전체 3 가지 과제 에서 수정의 빈도가 11 , 전체 비유창성 빈도가 29일 경우: $(11 / 29) \times$ $100=37.93 \%) \mathrm{OD}$ 와 SLD 범주 안에서 각각 순위를 구하였다(Table 8). HF-ASD 아동들은 OD에서 수정(30.83\%), 간투사(15.66\%), 다음절낱말반복(6.25\%), 구반복(2.41\%) 순으로 비유창성이 나타 났고, 이는 일반아동들의 OD 하위유형의 출현순위와 동일하며 두 집단 모두 수정이 간투사 보다 2 배에서 4 배까지 높게 나타났다(HFASD: 수정 $30.83 \%$, 간투사 $15.66 \%$; control: 수정 $47.54 \%$, 간투사 $12.31 \%)$ 반면, 말더듬 아동들은 수정과 간투사가 HF-ASD과 일반 아동들처럼 1과 2순위로 높게 나타났으나, 그 비율의 차이가 크지 않았다(수정: $19.27 \%$, 간투사: 16.56\%). SLD에서 HF-ASD 아동들 은 낱말부분반복(19.96\%), 깨진 낱말(9.67\%), 연장(7.45\%), 일음절 낱말반복(4.61\%), 막힘(3.17\%) 순으로 비유창성이 나타났다. HF$\mathrm{ASD}$ 아동들은 말더듬 아동과 동일하게 SLD에서 낱말부분반복이 1 순위로 가장 많이 나타났으나, 2순위에서 HF-ASD 아동들은 깨 진 낱말이, 말더듬 아동들은 막힘으로 비유창성 발화가 많이 나타 났다. 또한, 일반아동은 HF-ASD와 CWS 집단과 달리 SLD에서 깨 진 낱말이 1 순위로 가장 많이 나타났다. 이는 집단 간 비유창성의 하위유형별 출현순위가 OD보다는 SLD에서 차이를 보이며, HF$\mathrm{ASD}$ 아동들은 $\mathrm{OD}$ 중 수정이 가장 많이 나타났고, SLD 중 낱말부 분반복이 말더듬 아동들과 동일하게 가장 많이 나타났으나 막힘이
말더듬 아동들처럼 높은 비중을 차지하지 않음을 보여준다(HFASD: 3.17\%, CWS: 12.87\%).

\section{논의 및 결론}

본 연구의 목적은 다양한 발화상황에서 학령기 고기능 자폐스 펙트럼장애 아동들의 비유창성을 평가하여 말더듬 아동 및 일반 아동들과 어떠한 차이를 보이는지 살펴보고자 하였다. 지금까지 $\mathrm{HF}-\mathrm{ASD}$ 의 말산출 능력에 관한 연구는 매우 제한적이며 운율적인 측면에서 일부 설명이 시도되었으나 비유창성 측면에서는 거의 알 려진 바가 없으므로 본 연구의 결과들은 $\mathrm{HF}-\mathrm{ASD}$ 의 비유창성 특 성에 관한 증거기반의 초기 실험연구가 될 것이다.

먼저, HF-ASD 아동들의 OD 빈도는 3가지 발화과제에서 말더 듬 아동뿐 아니라 일반아동들과도 뚜렷한 차이를 보이지 않았다. $\mathrm{OD}$ 의 하위유형으로 간투사, 수정, 다음절낱말반복, 구반복으로 분리하여 세 집단 간의 차이를 살펴보았을 때도 $\mathrm{OD}$ 빈도는 집단 간 차이를 설명하지 못하였다. 그러나 $\mathrm{OD}$ 의 하위유형 비교에서 수 정과 간투사(세 집단 모두 수정: 1 순위, 간투사: 2순위)는 말더듬 아 동뿐 아니라 유창한 아동들에게서도 다른 형태의 $\mathrm{OD}$ 보다 더 높게 나타난다는 선행연구의 결과와 일치하였다(Jeon \& Kwon, 1998). 이 중 수정(예시: “혹부 욕심쟁이 혹부리 영감은”)이 세 집단 모두 가장 높은 비율을 차지하여 비록 집단 간 비유창성의 차이를 설명 하지는 못하더라도 HF-ASD 아동에게서 수정이 빈번히 나타난다 고 보고한 Stirling 등(2007)의 선행연구를 우회적으로 지지하며 자 폐스펙트럼장애를 대상으로 한 Scaler Scott 등(2014)의 연구에서 비유창성 형태 중 주저, 머뭇거림과 함께 수정을 주요 특성으로 제 시한 결과와도 일치하였다.

한편, 본 연구에서 SLD 빈도는 일반아동과 HF-ASD 아동을 구 별 짓는 요인으로 3 가지 발화과제 중 이야기 다시말하기 과제에서 일반아동보다 SLD의 빈도가 유의하게 높았고 그림 설명하기 과제 에서 통계적으로 유의하지는 않으나 일반아동보다 상대적으로 높 은 SLD 빈도(두 집단의 중위수 비교에서 HF-ASD 아동이 일반아 동보다 SLD 빈도가 4배 높음)를 보인 반면, 두 가지 과제에서 HF$\mathrm{ASD}$ 아동과 말더듬 아동은 유의한 차이를 보이지 않았다. 또한, $\mathrm{SLD}$ 의 하위유형별 집단 간 차이를 비교하였을 때도 일음절낱말반 복, 낱말부분반복, 연장에서 HF-ASD 아동이 일반아동보다 SLD 빈도가 유의하게 높았으나 말더듬 아동과는 유의한 차이를 보이지 않았다. 이와 함께, 본 연구의 질문에 포함하지 않지만 3 가지 발화 과제의 SLD 빈도를 모두 합친 전체 SLD 빈도(총 900음절에서 SLD 의 빈도수)에서 세 집단을 비교한 결과, 집단 간 유의한 차이가 나타 
났고 $\left(\chi^{2}=9.68, p<.01\right)$, Bonferroni 교정을 통한 사후검정에서 HF$\mathrm{ASD}$ 집단은 일반아동과 유의한차이를 보인 반면 $(Z=-2.38, p<.016)$, 말더듬 아동과는 유의한 차이를 보이지 않았다 $(Z=-.1 .65, p=.110)$. $\mathrm{SLD}$ 는 OD와 비교하여 보다 심각한 형태의 비유창성을 일컫는다. 따라서, 이들 결과들은 HF-ASD 아동들의 비유창성 정도가 말더 듬 정의의 핵심요인이자 청자들에게 보다 부정적인 영향을 미칠 수 있는 SLD 빈도에서 일반아동들보다 유의하게 높고 말더듬 아동들 과 유의한 차이가 없으므로 HF-ASD 아동들의 비유창성에 주의가 요구된다고 제안할 수 있겠다.

특히, HF-ASD 아동들의 SLD 빈도는 읽기를 제외한 두 가지 자 발화 과제에서 말더듬 아동만큼이나 높게 나타났다. 이는 과제의 특성에 따른 결과로 해석할 수 있으며 보다 복잡한 언어문맥 및 상 황에서 비유창성이 증가한다는 선행연구들과 일치한다(Gordon, 1991; Brown, 1945; Sung \& Sim, 2002; Lee, Han, \& Sim, 2004). 이 야기 다시말하기와 그림 설명하기는 단순히 글자를 해독하는 읽기 과제에 비해 언어적 요구가 증가하는 과제들이다. 즉, 이야기를 다 시 말하기 위해서 이전 내용들을 바르게 이해하고 기억하고 있는 지, 순서대로 이야기를 전달하고 있는지를 고려하면서 적절한 어휘 의 선택과 구문구조에 맞는 문장의 구성 및 산출이 동시에 이루어 져야 하므로 비유창성의 증가가 기대된다. 그림 설명하기 또한 읽기 과제보다 복잡한 언어문맥에서 구어 산출이 요구되므로 언어계획 및 구성, 실행과정에서 나타날 수 있는 어려움이 비유창성의 원인 일 수 있다. 무엇보다 HF-ASD 아동들이 읽기를 제외한 자발화 상 황에서 일반아동들보다 OD가 아닌 SLD 형태로 비유창성의 빈도 가 높다라는 점은 본 연구의 중요한 발견일 수 있겠다.

한편, 본 연구에서 $\mathrm{OD}$ 의 빈도는 3 가지 발화과제 모두에서 세 집 단 간에 유의한 차이를 보이지 않았으나, 집단 내 비교에서 세 집단 중 유일하게 HF-ASD 집단에서만 읽기과제보다 이야기 다시말하 기와 그림 설명하기 과제에서 $\mathrm{OD}$ 의 빈도가 유의하게 증가하였다. 이는 동일한 맥락에서 HF-ASD 아동들이 읽기과제보다 언어적 요 구가 높은 이야기 다시말하기와 그림 설명하기 과제에서 $\mathrm{OD}$ 유형 의 형태로 비유창성의 빈도가 증가하였다라고 해석할 수 있다. 그 러나 증가한 $\mathrm{OD}$ 의 빈도에도 불구하고 두 과제 모두에서 일반아동 들보다 유의하게 높은 결과를 도출해내지는 못하였다. 이들 결과들 을 종합해 보면, 읽기를 제외한 두 가지 자발화 과제에서 HF-ASD 아동들의 SLD 빈도가 일반아동들보다 높다는 점과 함께 두 과제 에서 비록 세 집단 간의 $\mathrm{OD}$ 빈도가 유의한 차이를 보이지는 않으 나 HF-ASD 집단 내 $\mathrm{OD}$ 빈도가 두 과제에서 유의하게 증가하므로 HF-ASD 아동들의 과제 유형에 따른 비유창성의 가변성이 SLD와 $\mathrm{OD}$ 유형의 비유창성에 함께 영향을 미치고 있음을 보여준다. 즉,
$\mathrm{HF}-\mathrm{ASD}$ 아동들은 읽기과제보다 자발화 과제에서 집단 간 SLD의 차이와 집단 내 $\mathrm{OD}$ 의 증가가 합해져서 그들의 비유창성이 더욱 두 드러지는 양상을 보이므로 청자들에게 부정적인 영향을 증폭시킬 수 있다. 따라서, HF-ASD 아동들의 언어적 문제 이외에 그들의 비 유창성 문제에 주의를 기울이고 비유창성을 개선하기 위한 적절한 평가와 효율적인 중재가 함께 고려되어야 하겠다.

Scaler Scott (2008)의 연구를 살펴보면, 아스퍼거증후군 집단과 말더듬 집단은 이야기 다시말하기 과제에서 내용을 수정하려고 시 도하는 과정에서 비유창성이 발생할 수 있으며 두 집단 간에 발화 중 내용을 수정하는 목적은 서로 다르다고 제안하였다. 말더듬 집 단은 말더듬는 순간을 회피하거나 탈출하기 위하여 내용을 수정 하는 반면, 아스퍼거증후군 집단은 생각한 내용을 다시 재형성하 기 위한 목적으로 내용을 수정한다고 하였다. 이는 아스퍼거증후 군 아동들이 정상범위의 언어능력을 가지고 있음에도 불구하고 화용적인 언어능력에 있어 매우 취약하여 특정 단어를 다양한 상 황에서 적절히 활용하여 적용하는 데 어려움을 보인다고 해석하였 다. 이러한 주장에 근거하여 HF-ASD 아동들 또한 낮은 어휘 활용 도를 가지므로 이야기 다시말하기와 그림 설명하기 과제에서 발화 산출 시 표현하고자 하는 어휘의 선택 및 활용에서의 어려움이 $\mathrm{OD}$ 및 SLD 유형의 형태로 비유창성의 빈도를 증가시켰다고 유추해 볼 수 있다. Scaler Scott (2015)은 또한 자폐스펙트럼장애 아동들이 보 이는 비유창성의 원인이 연결된 발화상황에서 발생하는 부담, 즉 대화에서 주어지는 정보를 유지하면서 생각의 흐름을 따라가야 하 는 부담에서 비유창성이 나타날수 있다고 제안하기도 하였다.

HF-ASD 아동들은 SLD의 하위유형 중 일음절낱말반복과 낱말 부분반복, 연장 빈도에서 말더듬 아동과 유의한 차이를 보이지 않 았으나 막힘 빈도에서 말더듬 아동들이 HF-ASD 아동들 보다 5 배 이상 높은 비유창성을 보였다(HF-ASD 막힘 빈도=.11; CWS 막힘 빈도=.58). 이는 HF-ASD 아동과 말더듬 아동의 비유창성 특성이 동일하지 않음을 시사한다. 앞서 전체 비유창성 중 SLD 빈도가 $\mathrm{HF}-\mathrm{ASD}$ 아동과 일반아동을 구별 짓는 중요요소이며 SLD 빈도가 말더듬 아동만큼이나 높다라는 사실을 강조하였다. 이때 SLD의 모든 하위유형에서 HF-ASD 아동과 말더듬 아동이 동일한 형태로 비유창하지 않으며 각 집단이 서로 다른 하위유형에서 비유창성의 특성이 강조된다는 점에서 막힘은 두 집단을 구별 짓는 핵심요소 로 제안될 수 있다. Byun, Lee와 Sim (2004)은 막힘을 운율이 깨진 발성(disrhythmic phonation, DP) 중 초기 말더듬 아동(만 2-7세) 이 가장 빈번하게 보인 비유창성 유형(막힘 $\rightarrow$ 연장 $\rightarrow$ 깨진 낱말 순)으 로 제안하였다. 선행연구의 연장선상에서 본 연구는 초기 학령기 말더듬 아동들(만 6-8세)도 DP 중 막힘이 가장 높은 비유창성 유 
형임을 제안할 수 있겠다.

또한, 본 연구의 흥미로운 결과는 아스퍼거증후군 관련 선행연 구들(Plexico et al., 2010; Scaler Scott et al., 2014; Sisskin, 2006)에 서 보고되었던 낱말 끝소리 반복이 HF-ASD 아동들에게서도 관찰 되었다는 점이다. 본 연구에서 낱말 끝소리 반복은 SLD의 하위유 형으로 따로 분류하지 않고 낱말부분반복에 포함하여 비유창성 빈도를 산출하였다. 연구에 참여한 7명의 HF-ASD 아동 중 4명의 아동들에게서 낱말 끝소리 반복이 관찰되었는데 전체 SLD에서 차 지하는 비율은 크지 않으나, HF-ASD 아동들에게도 이러한 형태 의 비유창성이 나타난다라는 점에서 중요한 발견일 수 있겠다. 낱 말 끝소리 반복은 “ 할아버지느-으-은”, “무서워서-어-어”, “나타 났습니다-아-아"와같은 형태로 나타났다.

본 연구의 제한점 및 후속연구를 위한 제언은 다음과 같다. 첫째, 본 연구에서 대상자 수가 적고 성별의 차이가 크므로 연구결과를 일반화하는 데 주의가 요구되며 후속연구에서 좀 더 많은 대상자 를 모집하고 성별의 차이를 줄여 HF-ASD 아동들의 비유창성 특 성을 연구할 필요가 있겠다. 둘째, 본 연구에서 대상자들의 말더듬 중증도가 통제되지 않았으므로 연구결과에 영향을 미쳤을 것으로 보인다. 따라서, 후속연구에서는 대상자들의 중증도를 균등화하고 세분화한 연구가 이루어질 필요가 있겠다. 셋째, 본 연구의 읽기과 제에서 대상자들의 읽기능력이 통제되지 않았으므로 읽기오류가 비유창성에 미치는 영향력을 배제시키기 위하여 후속연구에서는 읽기능력의 평가가 추가되어야 하겠다. 넷째, 선행연구에서 아스퍼 거증후군의 특징으로 제시되었던 낱말 끝소리 반복에 관하여 HF$\mathrm{ASD}$ 를 대상으로 한 연구가 추후에 이루어져야 하겠다. 본 연구에 서 HF-ASD 대상자의 수가 적고 낱말 끝소리 반복의 출현 빈도 또 한 높지 않았으나 HF-ASD 참가자 중 다수 $(57 \%$ 이상 $)$ 의 아동들에 게서 관찰되었으므로 연구의 의의가 있겠다. 끝으로, 본 연구의 실 험과제로 P-FA-II (Sim et al., 2010) 중 학령기 아동의 필수과제인 읽기, 이야기그림, 말하기그림을 사용하였다. 상호작용놀이 및 담 화와 같이 좀 더 자연스러운 상황에서 대상자들의 발화를 분석하 기 위하여 후속연구에서는 다양한 대화상황들을 추가하여 자발 화를 수집하고 여러 맥락에서 비유창성의 특성을 연구할 필요가 있겠다. 특히, 본 연구의 자발화 과제에서 300음절 이상의 발화를 수집하였으나 불분명한 발화와 함께 발화도입부의 50음절을 제외 한 200 음절을 자료분석에 사용하였다. 200 음절이 대상자의 일반 적인 발화를 대표하기에 제한점이 있을 수 있으므로 후속연구에서 는 자료분석의 음절수를 증가시킬 필요가 있겠다.

\section{REFERENCES}

Ambrose, N. G., \& Yairi, E. (1999). Normative disfluency data for early childhood stuttering. Journal of Speech, Language, and Hearing Research, 42, 895909.

American Psychiatric Association. (1994). Diagnostic and statistical manual of mental disorders (4th ed.). Washington, DC: Author.

American Psychiatric Association. (2013). Diagnostic and statistical manual of mental disorders (5th ed.). Washington, DC: Author.

Bagshaw, N. B. (1978). An acoustic analysis of fundamental frequency and temporal parameters of autistic children's speech (Doctoral dissertation). University of California, Santa Barbara, CA.

Baixauli, I., Colomer, C., Roselló, B., \& Miranda, A. (2016). Narratives of children with high-functioning autism spectrum disorder: a meta-analysis. Research in Developmental Disabilities, 59, 234-254.

Brown, S. F. (1945). The loci of stutterings in the speech sequence. Journal of Speech Disorders, 10, 181-192.

Byun, J. W., Lee, E. J., \& Sim, H. S. (2004). A study on the characteristics of speech disfluencies in early childhood stuttering. Korean Journal of Communication \& Disorders, 9, 1-14.

Charman, T., Drew, A., Baird, C., \& Baird, G. (2003). Measuring early language development in preschool children with autism spectrum disorder using the MacArthur Communicative Development Inventory (Infant Form). Journal of Child Language, 30, 213-236.

Cho, H. J., \& Lee, H. R. (2017). Spoken and written story production ability of school-aged children with high-functioning autism spectrum disorders. Communication Sciences \& Disorders, 22, 90-100.

Choi, J., Shin, H. B., \& Lee, Y. (2016). The relationship between acoustic and perceptual measurement of prosodic characteristics in children with highfunctioning autism spectrum disorders. Communication Sciences \& Disorders, 21, 735-743.

Choi, U. S., Kim, S. Y., Sim, H. J., Lee, S. Y., Park, S. Y., Jeong, J. S., ... \& Cheon, K. A. (2015). Abnormal brain activity in social reward learning in children with autism spectrum disorder: an fMRI study. Yonsei Medical Journal, 56, 705-711.

Fletcher, E. C. (1976). A comparison of pitch patterns of normal and autistic children (Doctoral dissertation). University of California, Santa Barbara, CA.

Fosnot, S. M., \& Jun, S. (1999). Prosodic characteristics in children with stuttering or autism during reading and imitation. Proceedings of the 14th In- 
ternational Congress of Phonetic Sciences, San Francisco, CA.

Goldfarb, W., Goldfarb, N., Braunstein, P., \& Scholl, H. (1972). Speech and language faults of schizophrenic children. Journal of Autism and Childhood Schizophrenia, 2, 219-233.

Gordon, P. A. (1991). Language task effects: a comparison of stuttering and nonstuttering children. Journal of Fluency Disorders, 16, 275-287.

Hargrove, P. M. (1997). Prosodic aspects of language impairment in children. Topics in Language Disorders, 17, 76-83.

Hietala, A., \& Spillers, C. (2005). Disfluency patterns in children with autism spectrum disorders. American Speech-Language Hearing Association Convention, San Diego, CA.

Jeon, H. S., \& Kwon, D. H. (1998). A syntactic characteristics of the stuttering children and normal children aged 4 years. Journal of Speech \& Hearing Disorders, 7, 129-147.

Keane, V. E. (1970). An investigation of disfluent speech behavior in Down's syndrome (Doctoral dissertation). University of Oregon, Eugene, OR.

Kim, Y. T., Hong, G. H., Kim, K. H., Jang, H. S., \& Lee, J. Y. (2009). Receptive \& expressive vocabulary test (REVT). Seoul: Seoul Community Rehabilitation Center.

Kjelgaard, M. M., \& Tager-Flusberg, H. (2001). An investigation of language impairment in autism: implications for genetic subgroups. Language and Cognitive Processes, 16, 287-308.

Klin, A., Volkmar, F., \& Sparrow, S. (2000). Asperger syndrome. New York, NY: Guilford Press.

Kover, S. T., Haebig, E., Oakes, A., McDuffie, A., Hagerman, R. J., \& Abbeduto, L. (2014). Sentence comprehension in boys with autism spectrum disorder. American Journal of Speech-Language Pathology, 23, 385-394.

Kover, S. T., McDuffie, A. S., Hagerman, R. J., \& Abbeduto, L. (2013). Receptive vocabulary in boys with autism spectrum disorder: cross-sectional developmental trajectories. Journal of Autism and Developmental Disorders, 43, 2696-2709.

Lee, E. J., Han, J. S., \& Sim, H. S. (2004). The effects of the phonetic complexity on the disfluencies and the articulation errors of people who stutter. Korean Journal of Communication \& Disorders, 9, 139-156.

Lee, H., Sim, H., Lee, E., \& Choi, D. (2017). Disfluency characteristics of children with attention-deficit/hyperactivity disorder symptoms. Journal of Communication Disorders, 65, 54-64.

Lim, J., \& Hwang, M. (2009). The characteristics of mazes in story retelling by children with attention deficit hyperactivity disorder. Korean Journal of Communication Disorders, 14, 96-108.
Moon, S. B., \& Byun, C. (1997). K-ABC (Korean Kaufman Assessment Battery for Children). Seoul: Hakjisa.

Nadig, A., \& Shaw, H. (2012). Acoustic and perceptual measurement of expressive prosody in high-functioning autism: Increased pitch range and what it means to listeners. Journal of Autism and Developmental Disorders, 42, 499-511.

O'Connor, N., \& Hermelin, B. (1994). Two autistic savant readers. Journal of Autism and Developmental Disorders, 24, 501-515.

Park, E. Y. (2011). Factor analysis of the Korean-child behavior checklist in children with autism spectrum disorders. The Journal of the Korea Contents Association, 11, 221-230.

Paul, R., Orlovski, S. M., Marcinko, H. C., \& Volkmar, F. (2009). Conversational behaviors in youth with high-functioning ASD and Asperger syndrome. Journal of Autism and Developmental Disorders, 39, 115-125.

Paul, R., Shriberg, L. D., McSweeny, J., Cicchetti, D., Klin, A., \& Volkmar, F. (2005). Brief report: Relations between prosodic performance and communication and socialization ratings in high functioning speakers with autism spectrum disorders. Journal of Autism and Developmental Disorders, 35, 861-869.

Plexico, L. W., Cleary, J. E., McAlpine, A., \& Plumb, A. M. (2010). Disfluency characteristics observed in young children with autism spectrum disorders: a preliminary report. Perspectives on Fluency and Fluency Disorders, $20,42-50$

Pronovost, W., Wakstein, M. P., \& Wakstein, D. J. (1966). A longitudinal study of the speech behavior and language comprehension of fourteen children diagnosed atypical or autistic. Exceptional Children, 33, 19-26.

Rutter, M., Mawhood, L., \& Howlin, P. (1992). Language delay and social development. In P. Fletcher \& D. M. B. Hall (Eds.), Specific speech and language disorders in children (pp. 63-78). London: Whurr.

Scaler Scott, K. (2008). A comparison of disfluency and language in matched children with Asperger's disorder, children who stutter, and controls during an expository discourse task (Doctoral dissertation). University of Louisiana at Lafayette, LA.

Scaler Scott, K. (2015). Dysfluency in autism spectrum disorders. ProcediaSocial and Behavioral Sciences, 193, 239-245.

Scaler Scott, K., Grossman, H. L., Abendroth, K. J., Tetnowski, J. A., \& Damico, J. S. (2007). Asperger syndrome and attention deficit disorder: clinical disfluency analysis. In J. Au-Yeung \& M. M. Leahy (Eds.), Research, treatment, and self-help in fluency disorders: new horizons. Dublin, Ireland: International Fluency Association. 
Scaler Scott, K., Tetnowski, J. A., Flaitz, J. R., \& Yaruss, J. S. (2014). Preliminary study of disfluency in school-aged children with autism. International Journal of Language \& Communication Disorders, 49, 75-89.

Shriberg, L. D., Paul, R., McSweeny, J. L., Klin, A., Cohen, D. J., \& Volkmar, F. R. (2001). Speech and prosody characteristics of adolescents and adults with high-functioning autism and Asperger syndrome. Journal of Speech, Language, and Hearing Research, 44, 1097-1115.

Schlanger, B. B. (1953). Speech examination of a group of institutionalized mentally handicapped children. The Journal of Speech and Hearing Disorders, 18, 339-349.

Schlanger, B. B., \& Gottsleben, R. H. (1957). Analysis of speech defects among the institutionalized mentally retarded. The Journal of Speech and Hearing Disorders, 22, 98-103.

Sim, H. S., Shin, M. J., \& Lee, E. J. (2010). Paradise-Fluency Assessment II. Seoul: Paradise Welfare Foundation.

Sisskin, V. (2006). Speech disfluency in Asperger's syndrome: two cases of in- terest. Perspectives on Fluency and Fluency Disorders, 16, 12-14

Stirling, L., Barrington, G., \& Douglas, S. (2007). Two times three little pigs: dysfluency, cognitive complexity and autism. Proceedings of 2006 Annual Meeting of the Australian Linguistic Society, St Lucia, Australia.

Sung, S. J., \& Sim, H. S. (2002). Relationships among utterance length, syntactic complexity, and disfluencies in preschool children who stutter. Korean Journal of Communication \& Disorders, 7, 102-129.

Tager-Flusberg, H. (2004). Strategies for conducting research on language in autism. Journal of Autism and Developmental Disorders, 34, 75-80.

Tsai, L. Y. (1992). Diagnostic issues in high-functioning autism. In E. Schopler \& G. B. Mesibov (Eds.), High-functioning individuals with autism (pp. 11-40). Boston, MA: Springer.

Yairi, E., Ambrose, N. G., \& Niermann, R. (1993). The early months of stuttering: a developmental study. Journal of Speech, Language, and Hearing Research, 36, 521-528. 


\section{국문초록}

\section{학령기 고기능 자폐스펙트럼장애 아동의 비유창성 특성 연구}

박희영 · 박혜연 · 원동란 · 김혜원 · 송승하 · 심현섭

이화여자대학교 대학원 언어병리학과

배경 및 목적: 본 연구는 읽기, 이야기 다시말하기, 그림 설명하기의 세 가지 발화과제에서 학령기 고기능 자폐스펙트럼장애 아동들 (HF-ASD)의 비유창성을 평가하고 과제에 따른 비유창성 특성이 말더듬 아동 및 일반아동들과 어떠한 차이를 보이는지 살펴보고자 하였다. 방법: 초등학교 저학년(만 6-8세) HF-ASD 아동 7명과 언어와 생활연령을 일치시킨 말더듬 아동 6명, 일반아동 8명을 연구대상 으로 세 가지 발화과제에서 집단 간 또는 과제 간 총비유창성(TD)과 정상적 비유창성(OD), 비정상적 비유창성(SLD)에 유의한 차이가 있는지 알아보았다. 결과: 집단 간 비교에서 HF-ASD 아동들의 OD 빈도는 세 가지 과제 모두에서 말더듬 아동 및 일반아동들과 유의 한 차이가 없었다. HF-ASD 아동들의 TD 빈도는 그림 설명하기 과제에서, SLD 빈도는 그림 설명하기와 이야기 다시말하기 과제에서 말 더듬 아동만큼 높게 나타났다. 집단 내 비교에서 HF-ASD 아동들의 TD 빈도는 읽기보다 이야기 다시말하기 과제에서, $\mathrm{OD}$ 빈도는 읽기 보다 이야기 다시말하기와 그림 설명하기 과제에서 유의하게 증가하였으나, SLD 빈도는 과제별로 유의한 차이를 보이지 않았다. 또한, $\mathrm{HF}-\mathrm{ASD}$ 아동들은 SLD의 하위유형 중 일음절낱말반복과 낱말부분반복, 연장 빈도에서 말더듬 아동들과 유의한 차이가 없었으나 막 힘 빈도에서 말더듬 아동들이 HF-ASD 아동들보다 유의하게 높게 나타났다. 논의 및 결론: 본 연구의 결과들은 HF-ASD 아동들이 읽 기를 제외한 발화상황에서 말더듬 아동들만큼 비유창하다는 사실을 뒷받침해준다. HF-ASD 아동들의 언어적 문제뿐 아니라 구어 산 출에서의 비유창성을 개선하기 위한 평가와 중재가 고려되어야하겠다.

핵심어: 고기능 자폐스펙트럼장애, 말더듬, 정상적 비유창성, 비정상적 비유창성

본 연구는 한국연구재단 BK21 플러스의 지원을 받았음(2017).

\section{참고문헌}

김영태, 홍경훈, 김경희, 장혜성, 이주연(2009). 수용·표현어휘력검사(REVT). 서울: 서울장애인종합복지관.

문수백, 변창진(1997). K-ABC 교육·심리측정도구(Korean-Kaufman Assessment Battery for Children: K-ABC). 서울: 학지사.

박은영(2011). 자폐 범주성 장애 아동에서 아동 청소년 행동평가척도의 요인분석. 한국콘텐츠학회논문지, 11, 221-230.

변재원, 이은주, 심현섭(2004). 초기 말더듬아동의 비유창성 특성 연구. 언어청각장애연구, 9, 1-14.

성수진, 심현섭(2002). 학령전기 유창성장애아동의 발화길이 및 통사적 복잡성과 비유창성의 관계 연구. 언어청각장애연구, 7, 102-129.

심현섭, 신문자, 이은주(2010). 파라다이스 유창성 검사II. 서울: 파라다이스 복지재단.

이은주, 한진순, 심현섭(2004). 조음 복잡성이 비유창성과 조음오류에 미치는 영향. 언어청각장애연구, 9, 139-156.

임종아, 황민아(2009). 이야기다시말하기에서 나타난 아동의 mazes 특성. 언어청각장애연구, 14, 96-108.

전희숙, 권도하(1998). 말더듬아동과 유창한 아동의 구문 특성 비교. 언어치료연구, 7, 129-147.

조현준, 이희란(2017). 학령기 고기능 자폐범주성장애 아동의 이야기 말하기와쓰기 특성. 언어청각장애연구, 22, 99-100.

최지은, 신희백, 이윤경(2016). 고기능 자폐스펙트럼장애 아동의 운율 특성에 대한 청지각적 및 음향학적 평가 간의 관계. 언어청각장애연구, 21, 735-

743. 